\title{
CREATIVITY CENTRED BRAND MANAGEMENT MODEL FOR THE POST- COVID MARKETING 5.0 WORLD
}

\author{
Dr. Arpan Yagnik \\ Penn State University, The Behrend College \\ Dr. Sujo Thomas \\ Amrut Mody School of Management, Ahmedabad University \\ Dr. Susmita Suggala \\ LJIMBA, Gujarat Technological University
}

\begin{abstract}
This article directly responds to the call for new visions that impact the field of brand communications in the Marketing 5.0 world. It does so by using creative principles to deconstruct and reconceptualise an important marketing management tactic namely brand management. Brand management is a polarizing tactic in the overall strategic marketing planning. It is easy to find scholars and practitioners in support of it as well as opposing it. This article reviews popular existing brand management strategies to see how creativity is treated and presents a new futuristic model of where and how should creativity be in the overall brand communication and management process. This model helps marketers take advantage of creativity principles. The model will reimagine the narrative of brand management and creativity will be included in the dynamic mix where the changes will hopefully have a deeper impact on the future brand management practices and its positioning in the overall marketing management.
\end{abstract}

Keywords: Creativity, Communication, Branding, Values, Strategy

\section{INTRODUCTION}

This article directly responds to the call for new visions that impact the field of brand communications in the Marketing 5.0 world. It does so by examining the existing approaches to brand management and presenting revisions in perspectives and approaches to brand management. Brand management is a key marketing management function. Every product manufacturer desires that the brand equity and brand value of his product increase consistently. The main reason why brand management is important is because brands have enjoyed a front row seat in the minds and hearts of consumers for over a century. Interestingly, it could be argued that the very reason why brands occupy the front row seat is brand management. Brands and brand management have had a successful run over the last century. However, brand management as a function is hitting a plateau. Last two decades have seen scholars and practitioners questioning the relevance and impact of brand management in its most recent avatar. There are hundreds of thousands of brands and if they are all choosing from the same pool of brand management strategies then it is likely that consumers become desensitized to the strategies and the efficiency of the strategy declines. Thus, it is important to not only include creativity in brand management but also to apply principles of creativity to creatively reimagine brand management, especially in the post coronavirus era where shopper, shopper behavior and shopper loyalties have either shifted or stalled.

Creativity is like the elusive unicorn. It is difficult to locate it. Forget locating it, not many even believe that it exists. Like it or not, you can use and have as many systems and models and data as you want but without the touch of creativity brand management is hollow. We believe that Creativity despite being an important element of brand management, is typically ignored in the brand management approaches and literature. This article highlights the neglect of creativity and argues for the explicit inclusion of creativity in brand management, and finally introduces and explicates a new creativity centred approach to brand management for the Marketing 5.0 world.

\section{BRAND MANAGEMENT}

Brand management is the set of actions taken to elevate a brand in the minds and hearts of the people. Brand management has gone 
through four phases in the last century. Branding per se goes way back but we will not be concerning our readers with the ancient history of branding and discuss the naming marks on the pots and pans or the branding marks on cattle. Time begins in this article from 1870s. The earliest brand managers were the founders themselves or the inventorowner themselves who were courageous enough to assume responsibility of their product. These were the individuals who proclaimed to the market that they had a substantial role to play in ensuring that a product reached to the market and therefore they were certain about the quality of the product. These individuals were vested and were interested in seeing their brand grow. They led the charge in doing so and their employees followed.

Then came a class of salaried employees who took upon the onus of making decisions pertaining to a product. There were two reasons for the shift of management function of brands from the owners to salaried professionals. 1) brand owners were by far too rich by now so they could afford creating new positions and supporting extra salary moreover, they also had the foresight that the profit this one manager would bring would by far exceed his salary, and 2) the expansion in the business operations did not leave sufficient time for the owners to be involved in day to day affairs. Both the reasons along with the increasing fashion of hiring managers to demonstrate the decentralization of decisionmaking power and a shift towards the concept of organization gave rise to the powerful managers of the brand.

Brand management, by the 1920s, mainly comprised of production, promotion and personal selling. Brand management executives were in close collusion with advertising agency as these agencies were believed to hold the key to market intelligence that would boost the demand for a brand. This collusion ultimately became one of the most successful symbiotic relations in the field of marketing management. Newer means and techniques of finding reliable information about consumers and identifying effective ways to promote a new product in a way to elevate it to the desired status of a brand under the direct supervision of an individual became a prominent practice. Proctor and
Gamble was the first to officially incorporate this system of managing the reputation of products in its organizational structure and since then all major corporations have adopted this system of brand management.

After second world war, brand management started getting standardized and its space in the organizational structure was also cemented. Brand managers held clout in organizations and its decisions. They symbolized dynamism, ownership, boldness, and the ability to break ground in uncharted territories. For the reader reading this, several of your closets and spaces in your home are filled with these brands that you relate to either due to the tangible or the intangible benefits and associations with attributes.

$21^{\text {st }}$ century has given businesses quite a few shocks financially, technologically as well as with the changing natures of their beloved customers. These shocks loosened the grips of many large businesses and subsequently also gave rise to entrepreneurs who were eager to make the most of the turmoil and the change to transform their offerings into brands. Most of these start-ups were and still are not in a position to afford brand managers. Many a times, start-ups have a Chief Marketing Officer (CMO) who also happens to be the incharge of logistics, accounting, sales and who also happens to be the founder-owner. This takes us back to the late $1800 \mathrm{~s}$ but a competitive advantage that today's founderowners have is technology and the documented knowledge of strategic brand management.

Brand management has worked tirelessly to assign products ranging from a soap to a car a special place in the minds and hearts of consumers. This marketing management function is responsible for some of the longest lasting relationships between a consumer and a product. Kevin Keller initially gave us one of the most popular explanation of strategic brand management through his book of the same title in 1997. His third edition came out in 2008 where he breaks down strategic brand management as activities that "involves the design and implementation of marketing programs and activities to build, measure, and manage brand equity" (Keller, 2008, p. 60). His approach to brand management comprises of four steps that begin with "Identifying and 
establishing brand positioning" followed by "planning and implementing brand marketing programs" and "Measuring and interpreting brand performance" and concluding with "growing and sustaining brand equity". His model is linear, and all the four steps require numerous tactics to achieve the goals of a given step. Recently, brand management has been explored from different perspectives in many studies and has been popular with researchers in domain areas such as online retail, digital media, tourism, fitness trackers, and cause-related marketing (Bhakar and Bhakar, 2020; Kushwaha et al., 2020; Thomas and Kureshi, 2020; Thomas et al., 2020a; Thomas et al., 2020b; Thomas et al., 2020c; Thomas and Kureshi, 2016; Kureshi and Thomas, 2020; Kureshi and Thomas, 2019).

\section{CREATIVITY}

Creativity is paramount for growth and progress. However, as mentioned before, creativity is the elusive unicorn and harnessing the elusive unicorn is not easy. Creativity as the ability to generate ideas that are novel and unique is a fairly popular definition of creativity used in scholarly literature. Martindale (1989) further analyzed the components of a creative idea and grouped the elements. The first element was a unique, original or novel idea, the second element was an idea with a meaningful functional use and the third element of the process was to implement the idea (Runco and Jaeger, 2012). The elusive unicorn in addition to the process has also been looked at from the lens of person, product, and place where each considers a different aspect of creativity such as the individual who generates creativity or the final creative output.

A comprehensive understanding of creativity can also be found in the FAQ section of the MacAurthur Foundation's Genius Grant webpage. It explains creativity and it gives examples of the several forms in which creativity can be found and applied. Despite being comprehensive and the favourite of the authors, it is broad and somewhat vague. The definition of creativity provided by Sir Ken Robinson is a good fit for the purposes of this article and henceforth we will be understanding creativity on the basis of that definition. Creativity, as he defines it in his popular TED Talk, is the ability to come up with an idea that has a value. This definition is also important because it inherently highlights the thought hierarchy. Creativity is at the bottom of the hierarchy; ideas are on top of creativity and innovation occupies the topmost spot. Another way to understand this is that creativity is like dry wood. Dry wood is the essential fuel required for fire. Fire is the idea. Just as how dry wood helps generate fire, creativity helps generates ideas. Some among many ideas receive widespread acceptance and those ideas transform into innovation which is commercialized and monetized. Creativity is a given in many aspects of marketing process such as product design and advertising. However, creativity is not a given when discussing brand management, which is an issue that this article highlights. Creativity provides unique competitive edge and advantage to the brand manager or a founderowner who is in the process of managing his brand.

\section{CREATIVITY AND MARKETING}

Marketing strives to add value to a company's offering and aims to appeal to the customers by persuading them to develop an intention to purchase and ultimately consume. A marketer strives to identify a unique set of values and novel ways to communicate with his target segments to grab a share of customer's mind. Creativity gives a message an extra edge and affords the message a faster reception and a longer retention in the minds of the customers resulting in a cumulative increase in brand recognition and sales in a cluttered market. Creative solutions increase the salience of the brand giving companies a competitive advantage over the others in the same product class. Savvy marketers have utilized creativity to gain more eyeballs and foot falls even with tight purse strings.

Marketing is about creating a meaningful differentiation for easy recognition and recall in a crowded marketplace (Wadden, 2011). Martindale (1989) emphasized the need for effective positioning for building a strong brand. He describes creativity as an original and useful idea irrespective of the field making creativity integral to the brand positioning process. Creativity injects a breakaway from the tradition by re-arranging existing elements of the marketing in a new and useful way. Organizations have recognized the need for creative methods as an effective way to promote product innovations. 
However, when the initiatives lack originality, they miss the mark in attaining the desired profitability causing frustration and lack of trust forcing the management to resort back to traditional methods of marketing (Andrew and Smith, 1996).

Another important aspect of marketing is advertising. Advertising exists to attract customers' attention for either building awareness, interest, desire or influence the purchase decisions of the customers. Several studies support the above observation that advertisements were developed to create a favourable image of the firm's offering and to create a positive opinion to increase both awareness and comprehensions (Yang and Smith, 2009; Till and Baack, 2005). A successful advertisement is a mix of important concepts including creativity (Hopkins, 1972; El-Murad and West, 2004). The novel ideas and messages appealed to the audiences resulting in higher brand awareness tilting the consumer attitudes in favour of the firm's offerings (Yang and Smith, 2009; Till and Baack, 2005). Both businessmen and consumers embraced creativity and acknowledged its significance in bringing about a positive and favourable change in the purchase decisions (Stump and Heide, 1996).

The concept of creativity in the marketing context is dealt in a limited way. Thus, exploring new ways to market products and services by adapting the concept of creativity is warranted (Andrews and Smith, 1996; Proctor, 1999). Research indicates that marketing managers need to be creative so as to empower their companies to thwart competition and thrive in a complex business environment (Proctor, 1999). However, creating quality content timely and quickly is a major difficulty that businesses have to counter (George \& Yagnik, 2017a). And with social media the need for such creative content has also sky rocketed. Moreover, with social media influencing brand-involvement (Pinto \& Yagnik, 2016), it is impossible to ignore it. The existence of creativity has been recognized as a significant competitive resource within corporations (Cook, 1998). As the business environment rapidly changes, marketing professionals too, recognize the dire need to manage brands effectively. Our suggestion here in this article is that it can be done so by using creativity.

\section{CREATIVITY \\ AND \\ BRAND \\ MANAGEMENT}

Brands have long been regarded as a point of sustainable differentiation (Aaker, 1996) and therefore, brand management has gained a lot of attention to academicians as well as marketing practitioners. Sutton and Kelley (1997) acknowledge the impact of creativity and emphasise it as a major constituent for crafting reputed brands. Van Gelder (2005) describes creativity not the same as innovation (applied creativity) or improvement/modification (routine creativity) and further asserts the inspirational role of creativity on brand. He also further advocates creativity to be an idea visualized differently or breeding an absolutely new idea which must be utilized while formulating a vision for a brand. Kao (1991, p. 14) defines creativity as "a human process leading to a result which is novel (new), useful (solves an existing problem or satisfies an existing need) and understandable (can be reproduced)".

Despite the fact that creativity is acclaimed by researchers, its prominence is restricted to specific industries and hence, does not derive its due importance in every society (Van Gelder, 2005). Jensen and Beckmann (2009) suggests that organizations to be successful in corporate branding should trust on a brand management philosophy embodied by creativity. Van Gelder (2005) states that creativity is one of the major influencing factors for managing the brand effectively across multiple markets and it becomes crucial for organizations to adapt creativity not in parts but in its entirety. Baack et al. (2016) suggests that creativity led to positive brand evaluations and emphasized the role of creativity in designing communication strategies. Further, Smith et al. (2008) states that creativity also results in better brand cognitions, positive attitudes towards brand and higher brand purchase intentions.

While searching the branding literature, we observe that, over the years, the concept of creativity has hardly been acknowledged as a constituent in any of the widely applied branding models, theories or framework's proposed in the public domain. Kapferer's (1999) proposes six brand management constituents: brand physique, culture personality, reflection, self-image and relationship. Likewise, De Chernatony (1999) 
advocates brand management in connection with brand identity management to reflect self-image of the stakeholder. In the similar way, Andriopoulos and Gotsi (2000) proposed a brand management framework based on internal employee-brand identity in creative organizations to build strong and reputed brand by enhancing the role of creativity within the organization. Although the literature as observed above, has acknowledged the significance of creativity in managing the brand, the brand management models have failed to breathe life into the concept of creativity and include it in the periphery of the vision. Henceforth, there is utmost need for mobilizing creativity within the organizations to manage the brand effectively and achieve the overall organizational goals (Andriopoulos and Gotsi, 2000).

Keller's (2008) approach to brand management comprises of the four steps as mentioned in a previous section. Here we look at each of the four steps closely. The tactics for the first step of strategic brand management, which is to identify and establish brand positioning and values which include competitive frame of reference, mental maps, points-of-parity and points-of-difference, brand mantra and core brand strategies. The second step of plan and implement marketing programs include the following tactics such as matching and mixing brand elements, leveraging secondary association and integrating brand marketing activities. Brand audits, brand value chain, and brand tracking are the tactics involved in the interpreting and measuring brand performance, which is the third step. The fourth and the final step of growth and nurture of brand equity includes tactics such as brand expansion strategies, brand portfolios and hierarchies, brand-product mix, and brand reinforcement as well as revitalization.

Upon closer examination and introspection, it becomes evident that creativity is pivotal for the tactics of each step. Let us look at some examples. The first step in Keller's (2008) approach to strategic brand management is of identifying and establishing brand positioning. He explains the objective of brand positioning by saying that it "is all about creating brand superiority in the minds of consumers" (Keller, 2008, p. 61). The emphasis is on the word creating using tactics such as mental map, brand mantra, brand associations, etc. Coming up with a brand mantra is a creative process and so is the establishment of brand superiority in the minds of consumers. The second step of planning and implementing brand marketing programs involves aspects such as brand logo, names, slogans, and more. All these require creativity. Impactful marketing programs require creativity to rise above the clutter, which in turn helps builds brand equity. Similarly, in the steps three and four too one can find abundant use of creativity in conceptualizing and executing the tactics to succeed in the brand management process. The same is true about numerous tactics of the six steps provided by Kepfrer and other approaches to brand management. However, despite the blatant and visible utility of creativity in the numerous tactics of the brand management process little to no emphasis is observed in including creativity or increasing creative quotient within the team overseeing the process. Creative proclivities are simply assumed to be there by default at an individual's disposal. Such neglect is unfortunate and must be changed for better.

\section{NEW APPROACH TO BRAND MANAGEMENT}

Brand management has already gone through four phases and changed avatars from time to time. With the entrepreneurial wave coming in strong and with it bringing numerous new brands accompanied by the shallow pockets it is time to start thinking about new avatars of brand management.

This process begins by thinking about the future of brands. Brands have successfully ruled over the psyche of people all over the world for more than a century. They became the central turning pole in a merry-go-around. The horses that go up and down are the brand managers. They have ups and downs on a cyclical basis. A myriad of things keeps revolving around the central turning pole. A critical question that needs to be asked here is that where can this central turning pole or otherwise a brand be placed on a diminishing marginal utility curve. What is a brand now? What is the guarantee it provides to consumers? What sort of pull it still has on the market and its consumers? If the notion of brand has run its course and the increment in its utility is negligible then very soon 
companies and manufacturers will have to turn to something else that can keep people running around it.

A brand is a promise, when an individual assumes responsibility of a product. Earlier, consumers were drawn to such gentlemanly behavior, but not anymore because over the years consumers have also learned about the bad behaviours and mal-intentions of these gentlemen. Hence, the emphasis on values and morals. Regardless of what a manufacturer intends to sell, the make or break deal here is, where and who your values are aligned with in the overall ecosystem. To be clear, the values referred here are different from what is commonly referred to as brand value in the branding literature. Values here mean the morals and beliefs that the organization behind the brand adheres to and stands by. Brands have suffered due to their misaligning values. The key point here is that brand identity which earlier comprised of tangible elements is now overtaken by intangible elements such as values and morals and actions and affiliations. Creativity is rising strongly among brands as a value that they prefer.

Regardless of the approach of brand management a manufacturer chooses to deploy, creativity enhancement of the individuals responsible for managing a brand is must. Without systematically injecting creativity in the process, a large majority of the tactics fall flat. Although Keller knew that creativity was an integral part of marketing and thereby brand management, he, like many others, chose to neglect/ignore discussing it in the main text of his seminal book. The reason why we choose the term neglect is because he very well knew the significance of creativity in branding and despite being aware of it did not include it in his text. The evidence of his awareness comes from his prologue where he fondly discusses his conversations with his father who was a rocket scientist. Keller (2008) agrees with his father that branding is not to be considered a rocket science because it is both an art and science. He further adds that "There's always a creativity and originality component involved with marketing" (Keller, 2008, p.14). Creativity disappears from the conversation afte the prologue. Thus, it is time for creativity to come out of the fringes and occupy a central and explicit role in the brand management process. Keping this in mind, Figure 1 presents the Creativity Centered Brand Management Model.

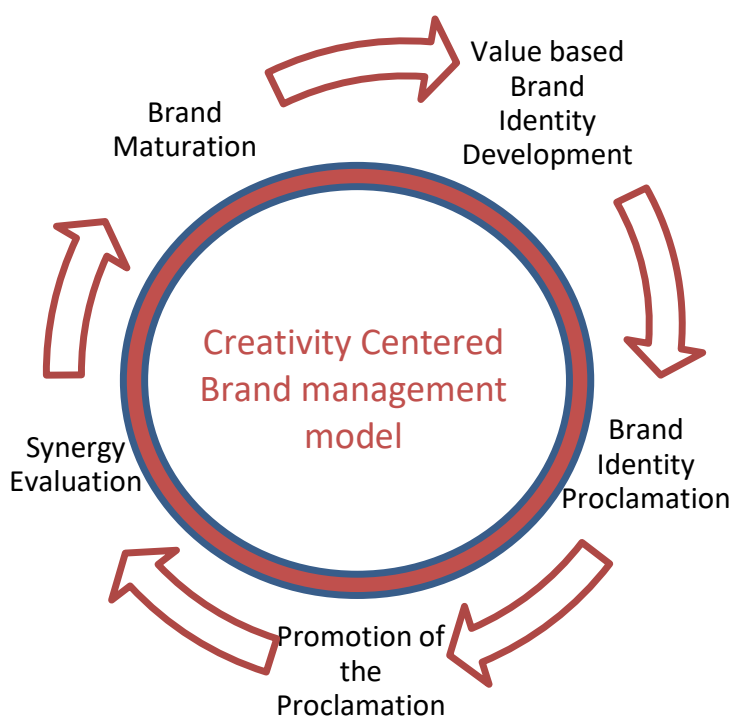

Figure 1: Creativity Centred Brand Management Model

As seen in Fig. 1, creativity is at the centre of the model. Creativity and creativity enhancement is critical at every step of the process. As opposed to the linear approaches in the previous models, this model has a cyclical approach which is representative of the continuous and cyclical changes in the process of brand management. There are five steps in the model and each will be explained in detail. In the new approach to brand management, we would like to focus initially on creativity and value based brand identity. Brand identity is one of the crucial functional component of the overall brand management process that aligns with the brand persona in the market. This model endorses the use of creative tools such as brain storming, creative aerobics (George \& Yagnik, 2017b) design thinking and more to develop a value-based brand identity. This is done keeping the primary, secondary, and tertiary benefits of the product in mind. Aaker (1996) states that the success of brand building lies in developing brand identity and further Ward et al. (1999) suggests that brand identity represents an in-depth understanding of the consumers, competitors, and business environment based on a trustworthy value linked to a service, product or firm. Organizations that concentrate on developing 
the brand identity add value to their market offerings and can eventually command premium price (Schmitt and Simonson, 1997). This approach does not typically discriminate between individuals that can actually purchase the product and the ones who cannot make the purchase. Branding, we feel, is about winning the minds and hearts of the people regardless of their pocket size.

Values that the brand endorses and adopts as part of its persona will drive the brand further. To do so a proclamation of the value-based brand identity has to be put in place. This proclamation sets the tone and boundaries through its endorsement of certain values. This proclamation is important because it automatically performs segmentation and positioning among audience. Audiences that do not relate with the values will move away from the brand whereas the ones that relate to it will be attracted to the brand. Another important thing that happens here is that a brand does not have to chase and cajole customers for loyalty. Loyalty to the values asserts loyalty to the brand. Brand identity stems from an organization and if the identity of the brand is strong in existence, then the customer experience leads to developing trust as well as loyalty and thus, helps in leveraging the brand.

By taking a closer look at the brand it could be defined as an accumulation of experiences and expectations (Kapferer, 2004) and that's precisely where creativity could play a better role in nurturing brand identity. Creativity thereby would lead to augment the process of brand management by supplementing to build a strong brand identity that would distinguish itself from the competitive offerings. The potential of creativity to tap inherent subconscious and psychological mind-set is unquestionable (Smith et al., 2008) and creativity could improve engagement with the message and enhance attitude and behavioural intention (Baack et al., 2016). Hence, the application of the concept of creativity facilitates establishing a flawless and uniform brand identity leading to the origination of a distinguished brand with unique characteristics. Moreover, creating loyalty and sustaining it over time is expensive. With this approach brand managers will be able to save precious dollars on creating and sustaining loyalty.
The next step is to creatively promote the proclamation of value-based brand identity. Promotion is one of the four Ps of marketing and there are six major promotional elements. Depending on the availability of budget and the nature of the offering (B2B or B2C) optimal promotional elements must be selected for launching an integrated marketing communication campaign to promote the values affiliated with the product along with the product. Advertising, PR, Social media marketing, direct sales, and more could be employed here in suitable combinations and all these require creativity, both in the creation of the marketing message and in the dissemination of the marketing message.

A critical next step in the process is of synergy evaluation. Given the changing ecosystem fuelled by technological advances in the last five years and exacerbated by the recent COVID-19 pandemic, synergy evaluation is more forward looking. Evaluations typically concerns itself with the evaluation of the activities of the past. Whereas, the creatively inspired synergy evaluation emphasizes on the synergy between the value-based brand identity and the prevailing as well as perceived shifts in the values of the society. A major strength of this model is that it does not emphasize as much on sales and instead focuses solely on the synergy between the value of the brands and the values of the prospective customers and society. This approach may be criticized but the rationale behind it is that as soon as things normalize, and the spending is up consumers will want to spend their dollars on a brand that already has a place and space in their minds and hearts. And to assess that the step of synergy evaluation is critical. This process stays loyal to the true purpose of branding which is to create place in the minds and hearts of the people which will eventually drive sales. This step and the model do not give sales objectives primary importance, instead it gives communication objectives and marketing objectives primary importance.

The final stage in the new approach before the cycle begins again is of brand maturation. This step is inspired heavily by the findings of previous step. Based on the findings of the synergy evaluation, additional values and persona aspects will need to be included in the brand identity. This evolution is referred to 
brand maturation. We choose to use the term maturity because it has a positive connotation and moreover a brand that relies heavily on value based identity should ideally mature and not grow. These changes that we refer to as maturation leads this process in to the first step again which is the development of value based brand identity. In other words, this is a constant process of development and refinement which is at every step inspired by creativity. The individuals involved in this process before they begin or are inducted into this process should have to go through intensive creativity enhancement programs where they are not only able to get reconnected with their creative potential but are also equipped with strategies that allow and enable them to jump out of the boxes at will.

The creativity centred brand management approach is a long-term approach with abundant flexibility to adapt to the external shifts in the market ecosystem as well as the value shifts of the society. This is what makes this approach unique and special. This is also what makes this approach a step towards a new direction of brand management and help it struggle less with relevance and significance in the overall marketing management.

\section{CONCLUSION}

The new model of brand management for Lean Marketing in the Marketing 5.0 world highlights the effectiveness of integrating creativity with the value based brand identity in the overall brand management process within the business organisations to ultimately leverage the brand and building a strong presence in the hearts and minds of the consumers. This article proposes a new approach for the explicit amalgamation of creativity and brand management and for advancement of new approaches at a theoretical level but are well aware that the proposed approach warrants investigation through empirical research to examine and validate the effectiveness of the approach. The article also acknowledges other factors highlighted by scholars (Jenson and Beckmann, 2009; Ghodeswar, 2008; Giarratana and Torres, 2007) which would influence this new approach to brand management, for instance, factors like employee independence, organizational climate, organizational capability, cultural uncertainty, product innovation or brand obsoleteness. For the purposes of theory advancement the above mentioned factors and other unaccounted factors are assumed as constants to nullify their effect on the approach. Further empirical research is required to understand and examine the impact of such variables individually and in combination along with their interaction effect.

In conclusion, this article provides an argument against the neglect of creativity in brand management, and present a revised approach to brand management utilizing creativity and making it the central driving force. For the reader to not just recognize and acknowledge the potential of creativity in amplifying brand management and its relevance in the overall marketing management in the Marketing 5.0 world but also to proactively apply is the hope of the authors.

\section{REFERENCES}

Aaker, D. (1996), Building Strong Brands, Free Press, New York, NY.

Andrews, J., \& Smith, D. C. (1996). In search of the marketing imagination: Factors affecting the creativity of marketing programs for mature products. Journal of Marketing Research, 33(2), 174-187.

Andriopoulos, C., \& Gotsi, M. (2000). Benchmarking brand management in the creative industry. Benchmarking: An International Journal. 7(5), 360-372.

Baack, D. W., Wilson, R. T., van Dessel, M. M., \& Patti, C. H. (2016). Advertising to businesses: Does creativity matter? Industrial Marketing Management, 55, 169177.

Bhakar, S. \& Bhakar, S. (2020). Impact of Price Promotion on Brand Equity Model: A Study of Online Retail Store Brands. Journal of Content, Community $\mathcal{E}$ Communication, 11(6), 124-142.

Cook, P. (1998). Best practice creativity. Aldershot, Gower Publishing, Ltd.

De Chernatony, L. (1999). Brand management through narrowing the gap between brand identity and brand reputation. Journal of Marketing Management, 15(1-3), 157-179. 
El-Murad, J., \& West, D. (2004). The definition and measurement of creativity: what do we know? Journal of Advertising Research, 44(2), 188-201.

George, L. C. C., \& Yagnik, A. (2017a) Creative Aerobics: Fueling Imagination in the 21st Century. Sage Publishers. New Delhi.

George, L. C. C., \& Yagnik, A. (2017b) Content and Creative Aerobics. (Editorial) Journal of Content, Community $\mathcal{E}$ Communication. 6(3). 1-2.

Ghodeswar, B. M. (2008). Building brand identity in competitive markets: a conceptual model. Journal of Product \& Brand Management, 17(1), 4-12.

Giarratana, M. S., \& Torres, A. (2007). The effects of uncertainty avoidance on brand performance: Marketing creativity, product innovation and the brand duration. Product Innovation and the Brand. Duration. Economics Working Papers 1015, Department of Economics and Business, Universitat Pompeu Fabra

Hopkins, C. C. (1972). My life in advertising. New York, N.Y.: Harper \& Brothers Publishers

Jensen, M. B., \& Beckmann, S. C. (2009). Determinants of innovation and creativity in corporate branding: Findings from Denmark. Journal of Brand Management, 16(7), 468-479.

Kao, J. (1991). Managing Creativity, PrenticeHall, Englewood Cliffs, NJ.

Kapferer (1999), quoted in De Chernatony, L. (1999). Brand management through narrowing the gap between brand identity and brand reputation. Journal of Marketing Management, 15(1-3), 157-179.

Kapferer, J. N. (2004). Brand NEW world, brand equity. The Economic Times, June, 30,7 .

Keller, K. (2008) Strategic Brand Management: Building, Measuring, and Managing Brand Equity. Pearson Education Inc. New Delhi.

Kureshi S. \& Thomas S. (2020). Testing the Influence of Message Framing, Donation Magnitude and Product Category in a Cause Related Marketing Context.
Journal of Marketing Communication, 26(3), 268-289.

Kureshi S. \& Thomas S. (2019). Online Grocery Retailing - Exploring Local Grocers Beliefs. International Journal of Retail $\mathcal{E}$ Distribution Management, 47(2), 157-185.

Kushwaha, B. P., Singh, R. K., Varghese, N., \& Singh, V. N (2020). Integrating social media and digital media as new elements of integrated marketing communication for creating brand equity, Journal of Content, Community $\mathcal{E}$ Communication 11(6), 52-64.

Martindale, C. (1989). Personality, Situation, and Creativity. In: John A. Glover, Royce R. Ronning and Cecil R. Reynolds, eds., Handbook of Creativity, New York, NY: Plenum Press, pp. 211232.

Pinto, M., \& Yagnik, A. (2016). Fit for Life: A Content Analysis of Fitness Tracker Brands use of Facebook in Social Media Marketing. Journal of Brand Management. doi: 10.1057/s41262-016-0014-4.

Proctor, T. (1999). The need for research into creativity in marketing. Creativity and Innovation Management, 8(4), 281-285.

Runco M. \& Garrett J. (2012) The Standard Definition of Creativity, Creativity Research Journal, 24:1, 92-96.

Schmitt, B., \& Simonson, A. (1997). Marketing aesthetics: The strategic management of brands, identity, and image. The Free Press, New York, NY.

Smith, R. E., Chen, J., \& Yang, X. (2008). The impact of advertising creativity on the hierarchy effects. Journal of Advertising, 37(4), 47-61.

Stump, R. L., \& Heide, J. B. (1996). Controlling supplier opportunism in industrial relationships. Journal of marketing research, 33(4), 431-441.

Sutton, R. I., \& Kelley, T. A. (1997). Creativity doesn't require isolation: Why product designers bring visitors "backstage". California Management Review,40(1), 75-91.

Till, B. D., \& Baack, D.W. (2005). Recall and persuasion: does creative advertising 
matter? Journal of Advertising, 34(3), 4757.

Thomas S. \& Kureshi S. (2020). Consumer skepticism towards cause related marketing: exploring the consumer tendency to question from emerging market perspective. International Review on Public and Nonprofit Marketing, 17, 225-236.

Thomas S., Kureshi S. \& Vatavwala S. (2020a). Cause-related Marketing Research (1988 - 2016): An Academic Review and Classification. Journal of Nonprofit $\mathcal{E}$ Public Sector Marketing, 32(5), 488-516.

Thomas S. \& Kureshi S. (2016). A study of Cause related Marketing initiatives and consumer insights - Evidences from Indian Context. South Asian Journal of Management, 23(2), 109-130.

Thomas S., Kureshi S., Bhatt V. \& Yagnik A. (2020b). Consumer engagement behaviour over time on Fitness tracker Facebook brand pages: Effect of post characteristics, message appeals and marketing promotions. International Journal of Business Information Systems (Article in Press)
Thomas S., Kureshi S. \& Yagnik A. (2020c). Examining the effect of message characteristics, popularity, engagement, and message appeals: Evidence from Facebook corporate pages of tourism organizations. International Journal of Business and Emerging Markets, 13(1), 3051.

Van Gelder, S. (2005). The new imperatives for global branding: Strategy, creativity and leadership. Journal of Brand Management, 12(5), 395-404.

Wadden, J., (2011). Marketing creativity: the influence of personal and proximal work factors on creative activity, The Marketing Management Journal, 21(2), 7080

Ward, S., Light, L., \& Goldstine, J. (1999). What high-tech managers need to know about brands. Harvard Business Review, 77(4), 85-85.

Yang, X., \& Smith, R. E. (2009). Beyond attention effects: modelling the persuasive and emotional effects of advertising. Marketing Science, 28(5), 935-949. 